\title{
Water Quality Control in a Miniature Shrimp Embankment*
}

\author{
WALUYO*, Nandang TARYANA, Andi ISMAYA \\ Department of Electrical Engineering, Institut Teknologi Nasional Bandung, \\ Jalan PHH Mustafa No. 23 Bandung 40124 Indonesia \\ waluyo@itenas.ac.id (*Corresponding author),yanztar17@gmail.com, andiismaya37@gmail.com
}

\begin{abstract}
Water quality is an important factor in creating the conditions needed for survival in a pond. The purpose of the research is to design a control system capable of maintaining the required water temperature and $\mathrm{pH}$, as vital parameters of water quality influences for shrimp growth in a miniature pond using a Zelio logic smart relay device. The water condition was controlled with the smart relay by employing the analog and digital inputs, and digital outputs. The control system was made up of two analog sensors for temperature and $\mathrm{pH}$ meters. An Arduino Uno microcontroller interfacing between a $\mathrm{pH}$ sensor and the Zelio, and the temperature and $\mathrm{pH}$ data charts and saved Excel files were the new proposed solutions. According to the results, the utilization of the aerator and water pump as a control method proved to be an effective procedure for keeping the temperature at around $25.4^{\circ} \mathrm{C}$. This control system produced the new temperature condition, which was within the specified range of $25-32^{\circ} \mathrm{C}$. Also, the $\mathrm{pH}$ was effectively maintained at the required range of 7.0-8.0. The system worked according to these parameters-the $\mathrm{pH}$ above 7.0 , and the temperature maintained below $32^{\circ} \mathrm{C}$, which could represent the required conditions of the water from the shrimp embankment.
\end{abstract}

Keywords: Analog, Digital, pH, Sensor, Temperature.

\section{Introduction}

The success in shrimp farming depends mainly on the proper management and quality in terms of water and soil parameters. Various studies have investigated some of the parameters like influence of water quality (Barman et al., 2017; Boyd, 2008; Bui, Van \& Austin, 2012; Chuntapa, Powtongsook \& Menasveta, 2003; Ferreira, Bonetti \& Seiffert, 2011; Habaki, et al., 2016; Milstein et al., 2005; Shaari et al., 2011). Generally, these studies concentrated on investigating the characteristics of water on the growth of shrimps. However, this research went a bit further by investigating water conditions required for the growth of shrimps. Therefore, it sets forth to design a control system capable of maintaining the required water temperature and $\mathrm{pH}$ for shrimp growth using a Zelio smart relay device (Schneider Electric, 2018). The Zelio smart relays are simple and easy troubleshooting (Diniş, Popa \& Iagăr, 2017), enable programming in Ladder Diagram (LD) and Function Block Diagram (FBD) (Diniş \& Popa, 2018).

\footnotetext{
*This paper is an extended version of the paper called "Perancangan Model Sistem Kontrol Parameter Kualitas Air Tambak Udang dengan menggunakan ZELIO SR3B101BD dan Arduino Uno", published in the 'ITATS Conference Systems, Seminar Nasional Sains dan Teknologi Terapan V' (SNTEKPAN V), October $19^{\text {th }}, 2017$, pages: B-181-B-188, http://conference.itats. ac.id/index.php/sntekpan/ 2017/paper/view/144. The current paper describes the actual research that has been conducted and subsequently completed while the in-depth analysis of results has been performed.
}

It also used an LM35; the temperature sensor produced $10 \mathrm{mV}^{\circ} \mathrm{C}^{-1}$. LM35 is high precision analog IC, wide range temperature sensor, not need additional calibration, economic and feasible (Liu et al., 2011), and proportional temperature to voltage conversion (Mahmud, Alam \& Ghosh, 2013; Kiruthika, Raja \& Jaichandran, 2017). The error percentage is very small, range from $0 \%$ up to $0.62 \%, 4-30$ working voltage (Amri et al., 2017).

The acceptance $\mathrm{pH}$ range for aquaculture is between 6.5 to 9.0 (Kayalvizhi et al., 2015). A $\mathrm{pH}$ sensor/meter requires a volume reaction and time detection ( $\mathrm{Li}$ et al., 2015), most common of glass electrode has a voltage output of potential metric (Chandanapalli, Reddy \& Lakshmi, 2014).

As a description, Atmega 328 could be utilized for generating digital signals (Hakim et al., 2018), laser communication system (Swami \& Jarali, 2017), various input and output monitorings and controlling (Chaudhari \& Chopade, 2016).

Generally, some researches utilized packet applications and analysis which used an Arduino microcontroller (Kayalvizhi et al., 2015) or ARM processor (Chandanapalli, Reddy \& Lakshmi, 2014) as the main component. Some research used ARM processors but limited in the analysis (Kiruthika, Raja \& Jaichandran, 2017).

This research involved mainly above devices for the controlling system in a miniature shrimp embankment. It utilized a Zelio smart relay due to simple and easy use, and availability of 
embedded digital and analog modules. A newly proposed solution was an input interfacing between the $\mathrm{pH}$ sensor and the Zelio smart relay utilizing an Arduino Uno microcontroller. While an operational amplifier (op-amp) was used as the input interfacing of the temperature sensor. Besides the output controls, the $\mathrm{pH}$ and temperature data were displayed in the chart forms and saved in Excel files by utilizing LabVIEW software (National Instruments, 2013). LabVIEW is effective demonstrating presentation (Kebairi, Becherif \& Bagdouri, 2015), interactive computeraided control system design (Keller, 2006), practical (Le, Pietrzak \& Shaver, 2014) and realtime tool (Yuan, Na \& Kim, 2018).

The research idea was first put forward in Taryana, Waluyo \& Ismaya, 2017, while the actual research has been conducted and the in-depth analysis of results has been performed by the current study. Therefore, the full implementation and comprehensive discussion are reported in this paper. Section 1 presents the background, component descriptions, closely related research reviews, and new proposed solutions. Section 2 presents the overall diagram, used component specifications, and both hardware and software designs. Furthermore, Section 3 reveals mainly the testing results and discussion. Finally, Section 4 gives the conclusion of the research results.

\section{Design Method}

Figure 1 shows the water quality control block diagram (Taryana, Waluyo \& Ismaya, 2017). Generally, its design and implementation system is made up of three segments - input, process, and output. The temperature and $\mathrm{pH}$ sensors gave commands to the system at the input. The LM35 was used as a temperature sensor. While the $\mathrm{pH}$ sensor used an analog $\mathrm{pH}$ meter equipped with a conditioning module of Arduino Uno microcontroller which produced voltage signals. The process was done by the Zelio smart relay and computer, both hardware and software. The monitoring data were displayed in chart forms and saved in Excel files by utilizing LabVIEW software in a computer. The output was the last part which related to the plant, the pump and aerator motors which switched by relays.

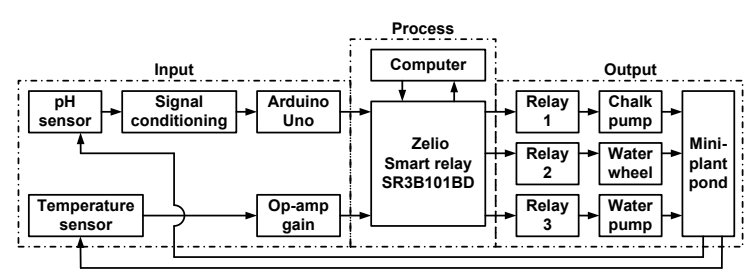

Figure 1. Water quality control block diagram

The system was designed in its temperature below $32^{\circ} \mathrm{C}$ and the $\mathrm{pH}$ between 6.8 and 8.2. Tables 1 to 6 show the lists of components used in the system. These components are the temperature sensor, Zelio smart relay, analog $\mathrm{pH}$ meter (DFRobot, 2008), ATmega328 (Atmel, 2010), permanent magnet dc motor and op-amp with their specifications for the design of the mini-plant which controlled the water quality.

Table 1. Temperature sensor

\begin{tabular}{|l|l|}
\hline Parameters & Descriptions \\
\hline Type & LM35 \\
\hline Operating temp. & $2-150^{\circ} \mathrm{C}$ \\
\hline $\mathrm{V}_{\text {in }}$ & $5 \mathrm{~V}_{\mathrm{dc}}$ \\
\hline $\mathrm{V}_{\text {out }}$ & $10 \mathrm{mV}_{\mathrm{dc}} /{ }^{\circ} \mathrm{C}$ \\
\hline
\end{tabular}

Table 2. Zelio smart relay

\begin{tabular}{|l|l|}
\hline Parameters & Descriptions \\
\hline Type & SR3B101BD \\
\hline Power supply & $24 \mathrm{~V}_{\mathrm{dc}}$ \\
\hline Input & 2 discrete +4 analog $(0-10 \mathrm{~V})$ \\
\hline Output & 4 relays, $24 \mathrm{~V}_{\mathrm{dc}}, 8 \mathrm{~A}\left(240 \mathrm{~V}_{\mathrm{ac}}, 8 \mathrm{~A}\right)$ \\
\hline Battery & Lithium \\
\hline Language & FBD/LD \\
\hline
\end{tabular}

Table 3. Analog $\mathrm{pH}$ meter

\begin{tabular}{|l|l|}
\hline Parameters & Descriptions \\
\hline Power supply & $5 \mathrm{~V}$ \\
\hline Size & $43 \mathrm{~mm} \times 32 \mathrm{~mm}$ \\
\hline Measuring range & $0-14 \mathrm{pH}$ \\
\hline Measuring temp. & $0-60^{\circ} \mathrm{C}$ \\
\hline Accuracy & $\pm 0.1 \mathrm{pH}\left(25^{\circ} \mathrm{C}\right)$ \\
\hline Response time & $\leq 1 \mathrm{~min}$ \\
\hline
\end{tabular}

Table 4. ATmega328

\begin{tabular}{|l|l|}
\hline Parameters & Descriptions \\
\hline $\begin{array}{l}\text { Operating } \\
\text { voltage }\end{array}$ & $5 \mathrm{~V}$ \\
\hline Use & $\begin{array}{l}\text { Analog input for } \mathrm{pH} \\
\text { processing voltage }\end{array}$ \\
\hline
\end{tabular}


Table 5. Permanent magnet dc motor

\begin{tabular}{|c|l|}
\hline Parameters & Descriptions \\
\hline Supply voltage & $3.3 \mathrm{~V}$ \\
\hline Use & Aerator in mini-plant \\
\hline
\end{tabular}

Table 6. Op-amp

\begin{tabular}{|l|l|}
\hline Parameters & Descriptions \\
\hline IC LM741 & $+5 \mathrm{~V} \&-5 \mathrm{~V}$ \\
\hline Function & $\begin{array}{l}\text { Excitation voltage of } \\
\text { LM35 temp. sensor }\end{array}$ \\
\hline
\end{tabular}

The design of the hardware system consists of the power supply, sensors, data processing unit, display, aerator, and pump subsystems. Figure 2(a) illustrates the Zelio smart relay subsystem while the mini-plant consisting of a mini pond, sensors, pump, and aerator is displayed in Figure 2(b) (Taryana, Waluyo \& Ismaya, 2017). The miniature pond dimension is $57 \mathrm{~cm} \times 37 \mathrm{~cm} \times 17 \mathrm{~cm}$, with around 18-liter water.

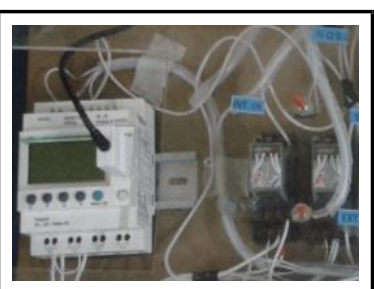

(a) Smart relay

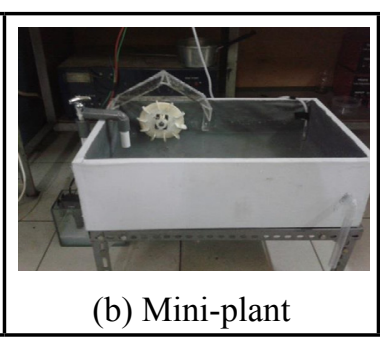

(b) Mini-plant
Figure 2. Miniature water quality control module

The temperature sensor subsystem, as shown in Figure 3(a), was designed to use LM35 and the output voltage was linearly measured over the temperature, with $10 \mathrm{mV}=1^{\circ} \mathrm{C}$, or as equation (1).

$T=\frac{V_{\text {out }}}{10 \mathrm{mV}}$

This output voltage could supply directly as input to the signal conditioning circuit, such as op-amp. Figure 3(b) shows the analog $\mathrm{pH}$ meter sensor (Taryana, Waluyo \& Ismaya, 2017).

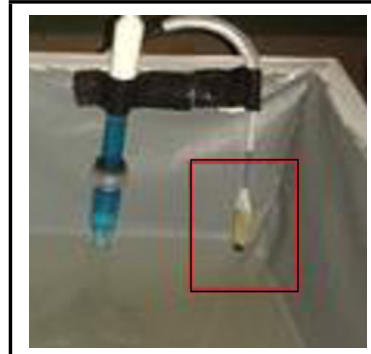

(a) Temperature sensor

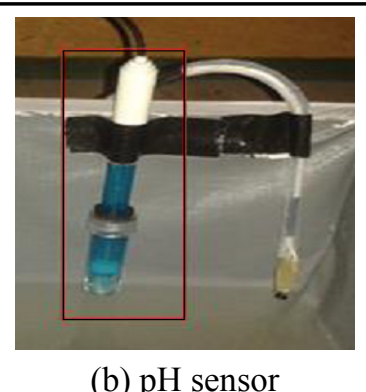

(b) $\mathrm{pH}$ sensor
Figure 3. Temperature and $\mathrm{pH}$ sensors

The temperature sensor was placed far away from the aerator so that it could receive an evenly distributed signal through the rotation of the aerator. The output voltage signal of the temperature sensor was very low, as $0.05 \mathrm{~V} /{ }^{\circ} \mathrm{C}$. Thus, it was necessary the op-amp for the signal amplification. The used op-amp, in this circuit, was the inverting device, with the magnification of 10 times the input voltage corresponding to what was supplied to the smart relay. The opamp circuit, made of two pieces of LM741 ICs, as the amplifiers, and the resistors were arranged in such a way as to produce a voltage up to ten times higher than the one of LM35. LM741 op-amp explores some parameters (Latina et al., 2017). Figure 4 shows the hardware of the op-amp IC LM741 circuit.

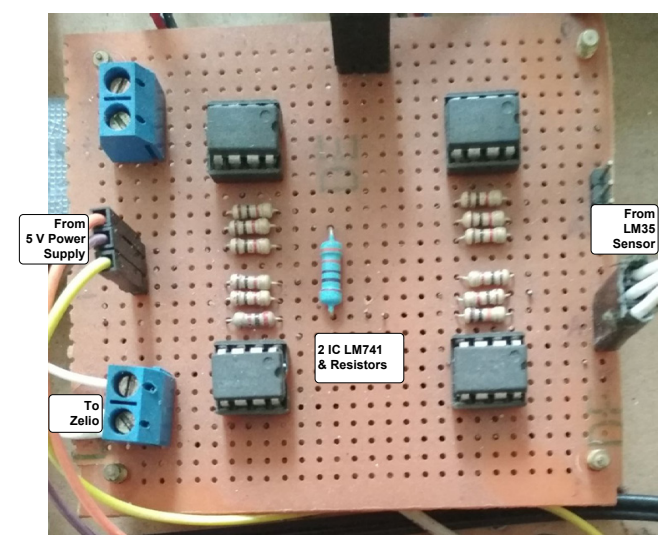

Figure 4. The hardware of the op-amp IC LM741 circuit

Figure 5 illustrates the inverting op-amp circuit. The first and second main resistors were $10 \mathrm{k} \Omega$ and $1 \mathrm{k} \Omega$ respectively, to obtain the ten times output voltage. Moreover, an inverted circuit with a multiplier factor was used to obtain a positive output voltage or written as equation (2), where $\mathrm{R}_{\mathrm{in} 1}, \mathrm{R}_{\mathrm{f} 2}$, and $\mathrm{R}_{\mathrm{in} 2}$ are $1 \mathrm{k} \Omega$, and $\mathrm{R}_{\mathrm{f} 1}$ is $10 \mathrm{k} \Omega$, in this research.

$V_{\text {out }}=\left(-\frac{R_{f 1}}{R_{\text {in } 1}}\right)\left(-\frac{R_{f 2}}{R_{\text {in } 2}}\right)$

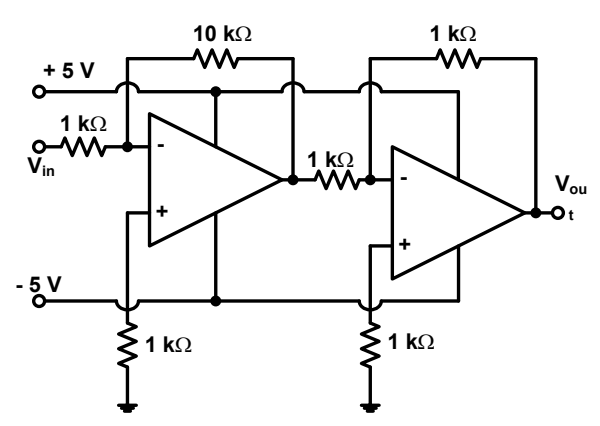

Figure 5. Inverting op-amp circuit 
Figure 6 shows the analog pH-meter module circuit. The output voltage was the one multiplied based on the sensor condition. Also, the generated voltage from the $\mathrm{pH}$ module was processed using the Arduino Uno microcontroller. The microcontroller was used as signal conditioning of $\mathrm{pH}$ sensor output signal of $0.059 \mathrm{~V} / \mathrm{pH}$ entering the Zelio. There was a coding command so that the $\mathrm{pH}$ value could be converted to the voltage and could be read by the Zelio.

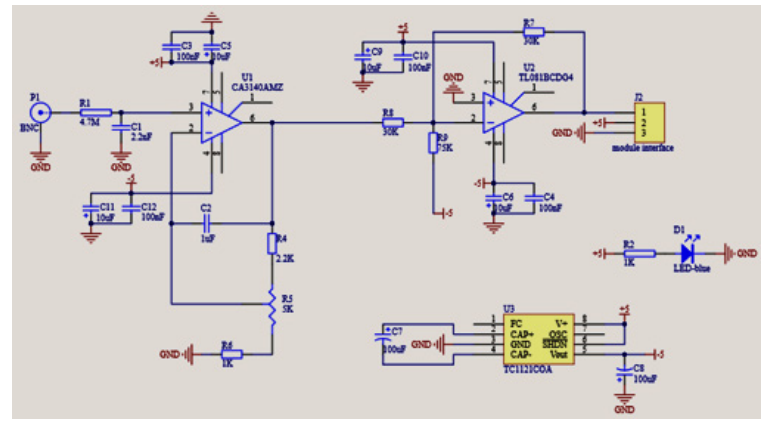

Figure 6. Analog pH-meter module circuit

The $\mathrm{pH}$ value could be calculated as equation (3),

$$
p H_{\text {meas }}=3.5 \times V_{\text {out }} \times \text { Offset }
$$

The water quality control module was constructed so that the Zelio was the main control component in achieving the desired water parameters. Its utilization was for avoiding a complicated PID control. It processed the input voltage signals from the microcontroller and made them give command signals to be the output signals. The voltage supplied from the power source was 24 $\mathrm{V} \mathrm{dc}$ and controlled the whole system. The data received from the $\mathrm{pH}$ sensor was first processed by the microcontroller, and the measured $\mathrm{pH}$ was displayed by the analog $\mathrm{pH}$ meter.

The power supply circuits, shown in Figure 7, provided three voltages needed for running the system -5 and $-5 \mathrm{~V}$ for the op-amp with the IC of LM741, 24V for the Zelio logic smart relay device and $3.3 \mathrm{~V}$ for the dc motor. Figure 8 displays the manner in which the supply circuits actually look like. In general, the $220 \mathrm{~V} \mathrm{AC}$ voltage was lowered using a transformer and then rectified to the $24 \mathrm{~V}$ $\mathrm{dc}$ while the output voltage of $9 \mathrm{~V}$ ac was rectified to the $5,-5$ and $3.3 \mathrm{~V}$ needed for the system (Texas Instruments, 1999; Texas Instruments, 2003; Texas Instruments, 2016).

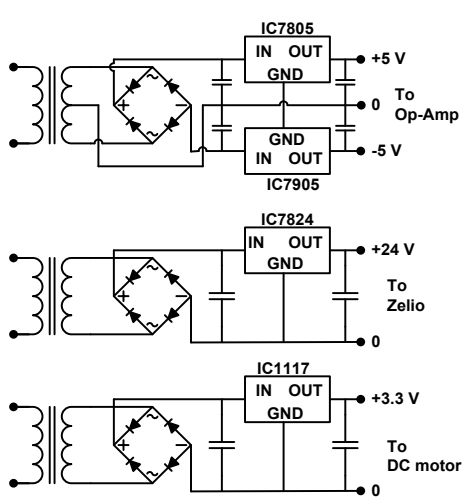

Figure 7. Power supply circuits (Taryana, Waluyo \& Ismaya, 2017)

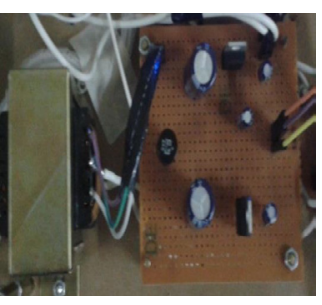

(a)

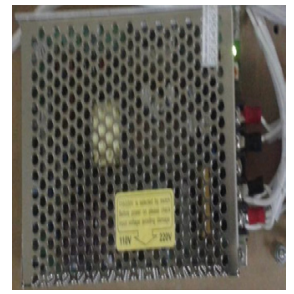

(b)
Figure 8. (a) $5 \mathrm{~V}$ and (b) $24 \mathrm{~V}$ power supply circuits

Figure 9 illustrates the flow chart of $\mathrm{pH}$ and the temperature sensing subprograms designed in one listing program, which displays the temperature, voltage, and $\mathrm{pH}$ values. The algorithm used a proportional control. As the $\mathrm{pH}$ and temperature above 7 and under $32^{\circ} \mathrm{C}$, the system was standby. If the $\mathrm{pH}$ value were equal to 7 or below, the base solution pump motor and aerator would be on. Otherwise, both motors would be off. If the temperature were equal to $32^{\circ} \mathrm{C}$ or above, the water pump and aerator motors would be on. Otherwise, both motor would be off. Figure 10 shows a part of the sensor listing program of LM35 using the Arduino Uno.

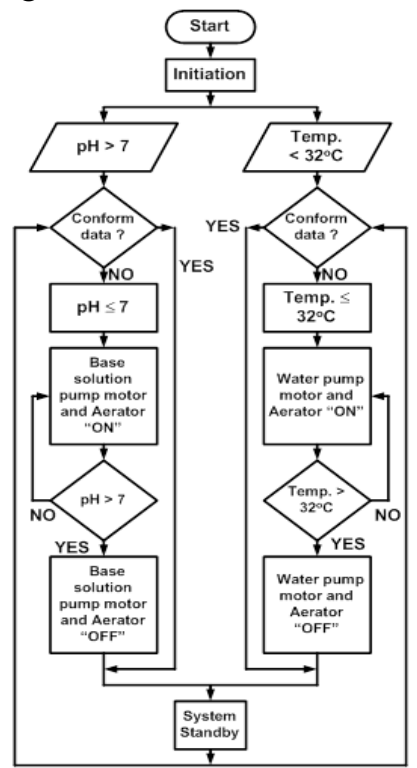

Figure 9. Flow chart of $\mathrm{pH}$ and temperature sensors 
If (time>10000)

Serial.print ("V1:"),

Serial.print (voltage, 2);

Serial.print ("pH value:");

Serial.print (pHValue, 2 );

Serial.print ("temp: ");

Serial.print (tempc, 2);

serial.print ("V2:");

Serial.print ln $(\mathrm{V} 2,2)$;

//digital Write (LED, digitalRead (LED) ^1) ;

/ / printTime=millis ();

delay (500):

Figure 10. A part of the LM35 sensor listing program

Figure 11 shows a part of the microcontroller listing program also with the parameters displayed by using the Arduino Uno.

pHÄray [pHÄray Index++] =analogRead (SensorPin); if ( $\mathrm{pHAr}$ ray Inde $==$ Ar ray Lenth) pHAr ray Inde $\mathrm{x}=0$;

voltage=avergearray (pHArray, Arraylenth) *5. 0/1024; pHValue $=3.5$ * voltage + of fset;

samplingT ime $=$ millis ();

if (millis ()-printTime>printInterval)//Every $800 \mathrm{~m}$ of the LED indicator \{

int analogPin=voltage;

val=analogRead (analogRin) $/ / /$ read the input pin

//analogritite (LED, val/4);//analogRead values go $f$

Figure 11. A part of the microcontroller program

The constructing program with LabVIEW was to display the temperature and $\mathrm{pH}$ data from the microcontroller on a computer. In this research, the role of LabVIEW is for the monitoring of voltage signals from the temperature and $\mathrm{pH}$ sensors in the form of charts and saving the data in Excel files.

The overall wiring control system is shown in Figure 12. The input is composed of the temperature and $\mathrm{pH}$ sensors, with other supporting devices, the microcontroller, and op-amp. The main controller is made up of the Zelio smart relay while the output is made up of the pump and aerator motors.

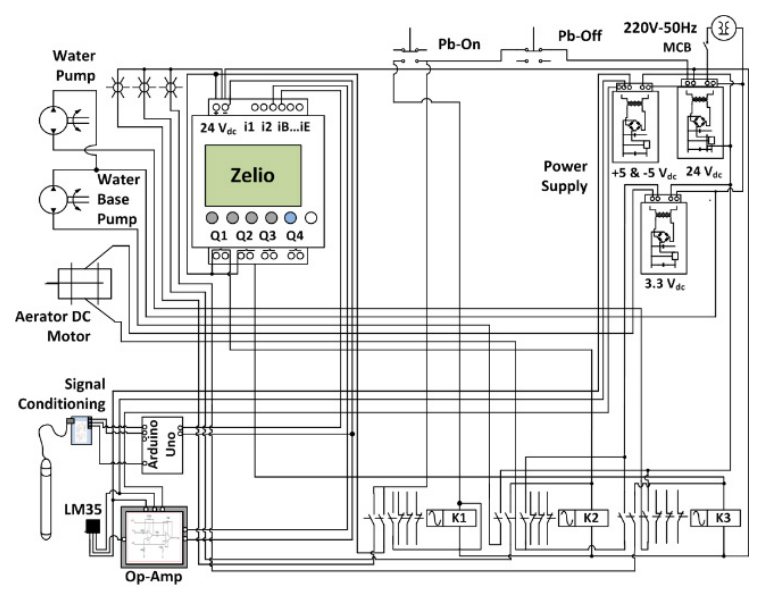

Figure 12. Overall Control System

\section{Results and Discussion}

Figure 13 displays the block diagram created by the LabVIEW program for monitoring and storing temperature and $\mathrm{pH}$ data.

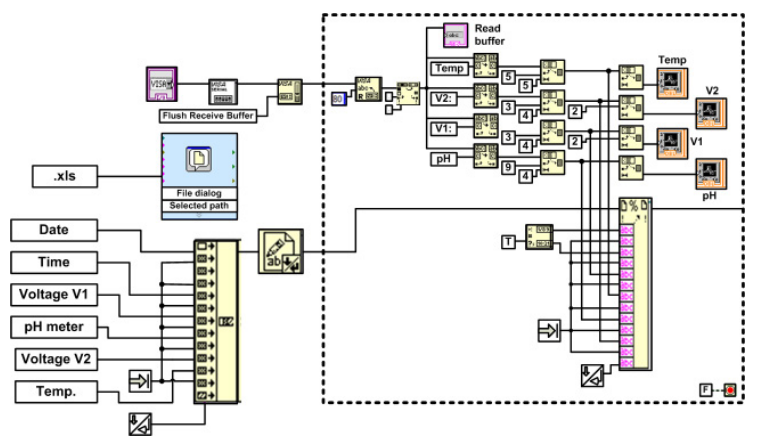

Figure 13. Temperature and $\mathrm{pH}$ monitoring block diagram in LabVIEW

The program design in the Zelio software used Function Block Diagram (FBD) language, as shown in Figure 14, with the input in the analog signal forms. The Zelio received the analog input voltage from the transducers, which was then used to control the output system.

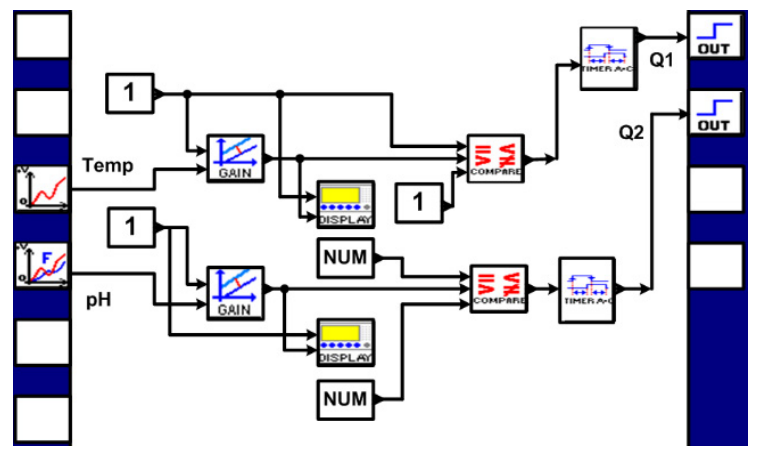

Figure 14. Design display of temperature and $\mathrm{pH}$ (Taryana, Waluyo \& Ismaya, 2017)

The water quality control design and implementation modules were necessary for testing. Also, the testing of the sensor subsystems was conducted to see the sensor response with the required parameters. The testing of the LM35 temperature sensor was carried out because it converted the output temperature to voltage.

The voltage is shown in Figure 15(a) before amplification was $269.9 \mathrm{mV}$. It changed to $2.789 \mathrm{~V}$ after amplification, using IC LM41, as shown in Figure 15(b). With this voltage, the measured temperature was $26.99^{\circ} \mathrm{C}$. The voltage amplification in IC LM741 resulted in the output voltage around ten times the voltage from LM35. 
Also, the $\mathrm{pH}$ sensor testing was carried out to find out how the sensor responded to variation in $\mathrm{pH}$. This analysis was achieved by adding a large volume of acidic liquid to it and then observing the changes, as shown in Figure 16.

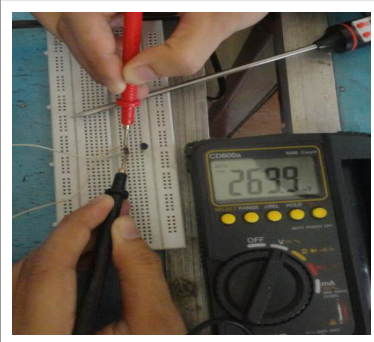

(a) Before amplification

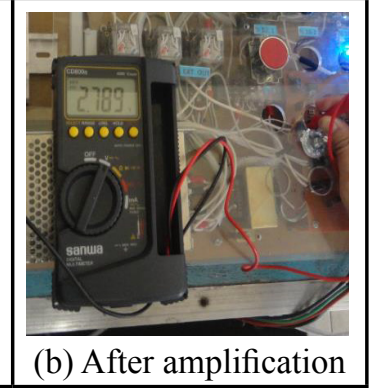

(b) After amplification

Figure 15. Measurements of LM 35

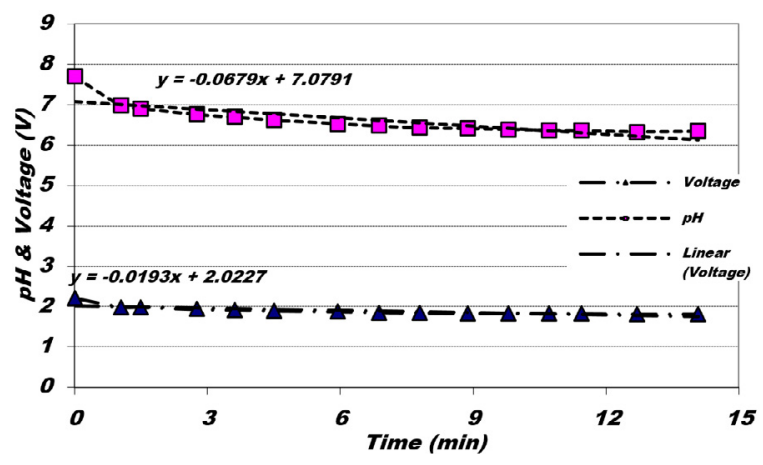

Figure 16. pH sensor testing

The results showed a decrease in the $\mathrm{pH}$ and in the generated voltage as it was recorded by the $\mathrm{pH}$ sensor. This testing was conducted to determine the response of the sensor when experiencing changes in $\mathrm{pH}$ levels in the miniplant. Moreover, the $\mathrm{pH}$ testing of the fish pond was carried out to determine the actual $\mathrm{pH}$ levels for further reference. It was found to be above 7.0, meaning it was in normal condition. Figure 17 shows the $\mathrm{pH}$ measurement chart from an actual fish pond sample in Ujung Berung, Bandung. The measurements were made for 30 minutes, and the average $\mathrm{pH}$ was normal, as 7.904 with $7.586 \%$ standard deviation.

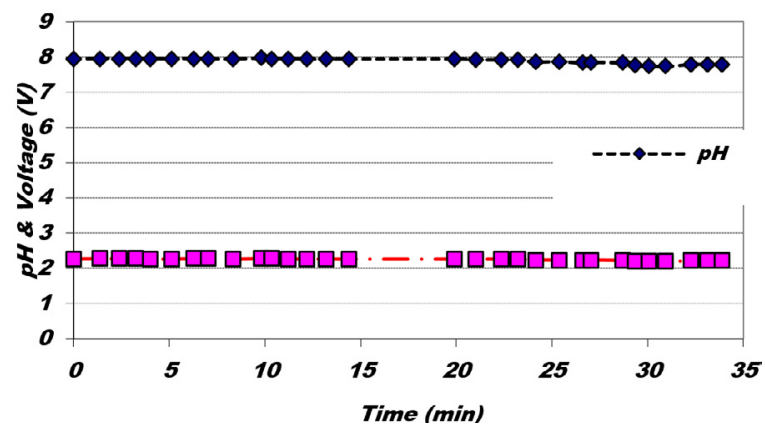

Figure 17. $\mathrm{pH}$ Measurement chart of the fish pond
The measurements were directly taken from the pond under sunny conditions, and there was a change in the $\mathrm{pH}$ level. This indicated that the condition of the water in the fish pond could change at any time. However, it was still normal, with a value above 7.0. Then, the mini-plant testing was conducted to determine the response of the sensors to changes in the water condition. These were carried out in three stages - the normal condition, the $\mathrm{pH}$, and temperature responses.

The normal condition testing was performed to determine the temperature and $\mathrm{pH}$ conditions before the experiments, as shown in Figure 18. The $\mathrm{pH}$ was above 7.0, with an average of 7.33, while the temperature was around $25^{\circ} \mathrm{C}$, with an average of $25.07^{\circ} \mathrm{C}$. The results showed that the changes in $\mathrm{pH}$ were still within the normal limits. This was because the water was not completely homogenous, thereby giving slight changes in the $\mathrm{pH}$ readings. The temperature was also within the normal limits, although there were some variations of $0.04-0.06^{\circ} \mathrm{C}$. These minute changes were caused by the noise generated from using the LM35 sensor, which produced heat, hence, the slight changes from the temperature readings of $25^{\circ} \mathrm{C}$. Based on the trend line, the $\mathrm{pH}$ and temperature only very slightly increased. This was probably caused by ambient temperature and sensor generated heat.

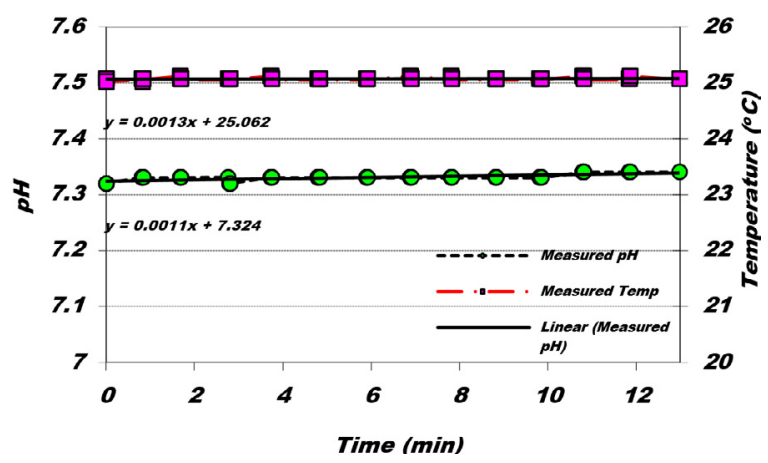

Figure 18. The measured $\mathrm{pH}$ and temperature for normal condition

Figure 19 illustrates the responses of $\mathrm{pH}$ and temperature sensors when adding an acidic solution. The $\mathrm{pH}$ sensor was directly placed in the water of the mini-plant to record any change (Taryana, Waluyo \& Ismaya, 2017).

Considering the chart, the initial $\mathrm{pH}$ was 7.3 and decreased upon adding an acidic solution. When

https://www.sic.ici.ro 
the $\mathrm{pH}$ was under 7.0 , the system automatically worked until it was above the normal value. This decline occurred between 5.33 and 14.33 minutes when the $\mathrm{pH}$ was 6.9 so that the control method responded to that value and activated the lime pump motor and aerator to raise the $\mathrm{pH}$. The increase showed at 15.25 minutes until the $\mathrm{pH}$ value of the pond was normal. Then, there was a small rise in the temperature of $0.24^{\circ} \mathrm{C}$ at 17.18 minutes, but it did not affect the normal condition of the mini-plant.

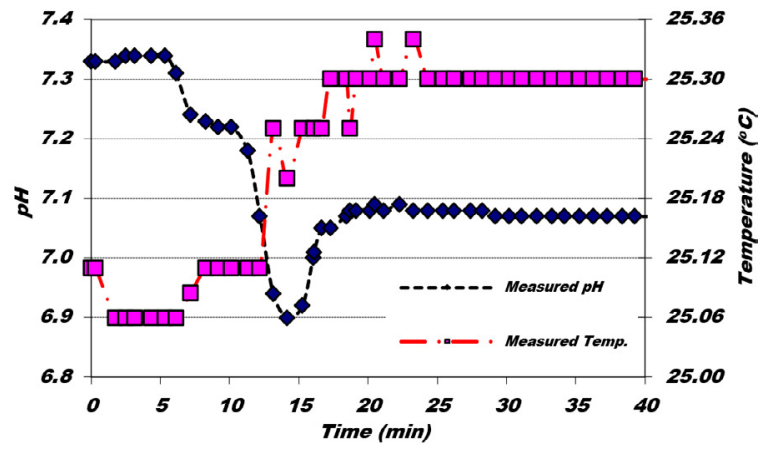

Figure 19. $\mathrm{pH}$ and temperature responses due to the addition of the acidic solution

Figure 20 shows the $\mathrm{pH}$ responses due to changes in the temperature. The measured $\mathrm{pH}$ responses were obtained from the measurements of the temperature changes in the mini-plant. The used LM35 temperature sensor was placed directly in the water of the mini-plant but far from the aerator. The $\mathrm{pH}$ value was relatively stable as the temperature slightly increased.

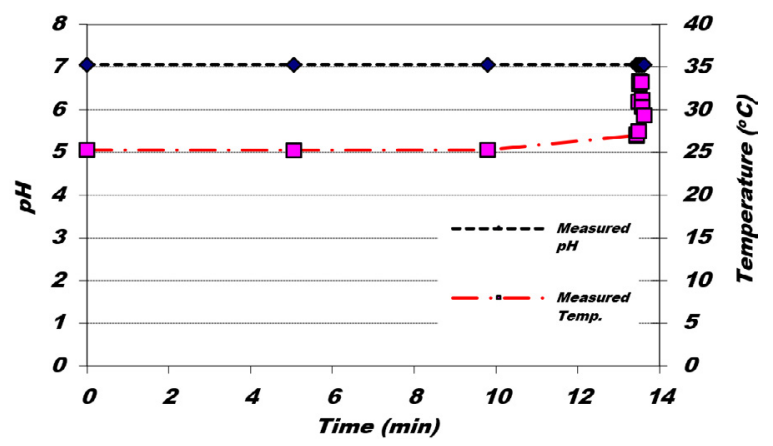

Figure 20. $\mathrm{pH}$ responses due to temperature

Figure 21 displays the $\mathrm{pH}$ and temperature voltage charts as functions of time. The $\mathrm{pH}$ voltage was constant at $2.02 \mathrm{~V}$, while the temperature voltage experienced a slight increase, with the average increment rate of $0.005 \mathrm{~V} / \mathrm{min}$. This was probably caused by the heat generated by the sensor.

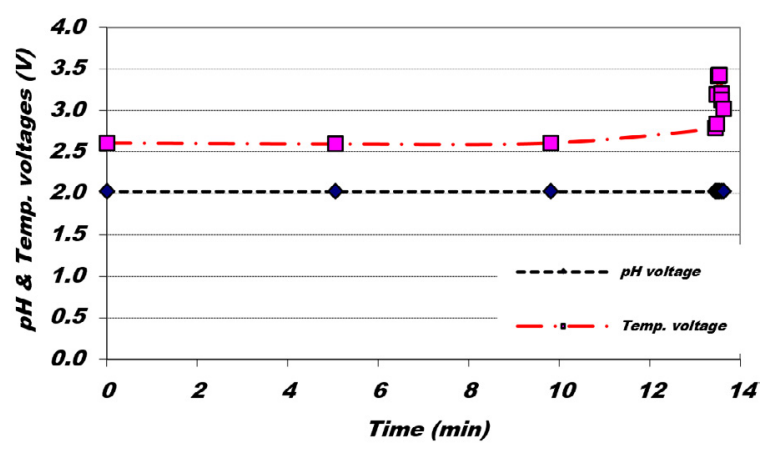

Figure 21. $\mathrm{pH}$ and temperature voltages

The temperature testing was conducted when the temperature of the water in the mini-plant increased, concerning the temperature for the normal pond condition. The system was designed such that the water temperature was under $32^{\circ} \mathrm{C}$, which is the normal limit for the shrimp habitat as any condition with the value above. This could affect the survival of shrimp in the pond. The temperature of the mini-plant increased at 13.48 minutes till 13.55 minutes when it reached a maximum of $33.25^{\circ} \mathrm{C}$ and activated the water pump and aerator. After the aeration, the temperature decreased to $31.17^{\circ} \mathrm{C}$ at 13.58 minutes and then to $29.32^{\circ} \mathrm{C}$ at 13.62 minutes.

Figure 22 shows the chart of temperature versus the temperature voltage, and since the chart was linear, the voltage was equivalent to the temperature with its average rate of $9.64^{\circ} \mathrm{C} / \mathrm{V}$.

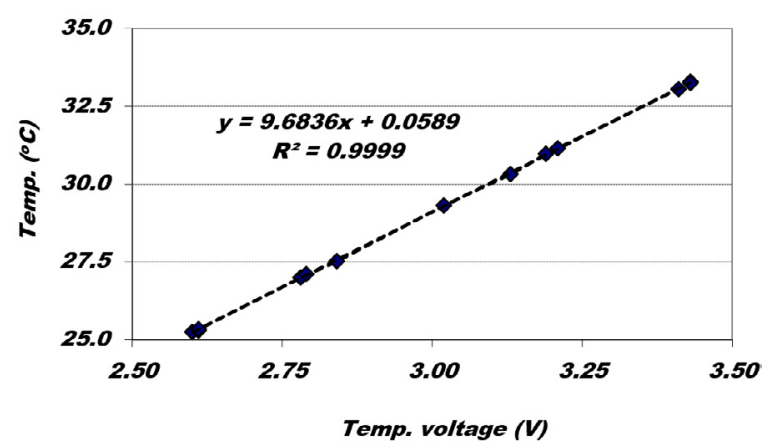

Figure 22. Temperature versus temperature voltage

The rating voltage of the aerator permanent magnet motor is $24 \mathrm{~V}$. Nevertheless, it was supplied by $3.3 \mathrm{~V} \mathrm{dc}$, and it consumed 2.4 watts to be slow rotation. By this power, the aerator was visually enough for stirring the 18-liter water. Nevertheless, the relation between the consumed power, water volume, and viscosity should be conducted in further research. Besides on the site pond data and revealed in (Kayalvizhi et al., 
2015), as comparisons, Table 7 lists some samples from the previous researches on the temperature and $\mathrm{pH}$ ranges or averages on the aquaculture of shrimp habitat.

The temperature and $\mathrm{pH}$ of research results ranged from 25.1 to $25.11^{\circ} \mathrm{C}$ with the average of $25.07^{\circ} \mathrm{C}$, and 7.32 to $7.34 \mathrm{pH}$ values, with the average of 7.33 for the normal condition, and 25.085 to $25.34^{\circ} \mathrm{C}$, with the average of $25.23^{\circ} \mathrm{C}$, and 6.9 to $7.34 \mathrm{pH}$ values, with the average of $7.12 \mathrm{pH}$ value for the addition of the acidic solution. Thus, based on the references, both parameters were generally in the range of shrimp growth, with an assumption that the remaining parameters were almost the same.

Table 7. Temperature and $\mathrm{pH}$ values of aquacultures

\begin{tabular}{|c|c|c|c|}
\hline No & $\begin{array}{c}\text { Temperature } \\
\left({ }^{\circ} \mathrm{C}\right)\end{array}$ & $\mathrm{pH}$ & References \\
\hline 1 & $\begin{array}{l}28.4-28.54 \\
\text { (treatment) }\end{array}$ & $\begin{array}{c}8.5-8.65 \\
\text { (treatment) }\end{array}$ & $\begin{array}{c}\text { (Tahe \& } \\
\text { Suwoyo, 2011) }\end{array}$ \\
\hline 2 & $\begin{array}{l}28.2-28.5 \\
\text { (average) }\end{array}$ & $\begin{array}{c}8.0-8.5 \\
\text { (average) }\end{array}$ & $\begin{array}{c}\text { (Tahe \& } \\
\text { Nawang, 2012) }\end{array}$ \\
\hline 3 & $30.31-33.5$ & $8.51-9.79$ & $\begin{array}{c}\text { (Pirzan \& } \\
\text { Utojo, 2013) }\end{array}$ \\
\hline 4 & $\begin{array}{l}18-26 \\
\text { (range) }\end{array}$ & $\begin{array}{l}5.7-9.1 \\
\text { (range) }\end{array}$ & $\begin{array}{l}\text { (Chandanapalli, } \\
\text { Reddy \& } \\
\text { Lakshmi, 2014) }\end{array}$ \\
\hline 5 & $28.7-33.8$ & $7.0-8.3$ & $\begin{array}{c}\text { (Mangampa, } \\
\text { 2015) }\end{array}$ \\
\hline 6 & $\begin{array}{l}26.03-30.08 \\
\text { (range) }\end{array}$ & $\begin{array}{l}6.42-8.88 \\
\text { (range) }\end{array}$ & $\begin{array}{c}\text { (Makmur et al., } \\
\text { 2018) }\end{array}$ \\
\hline
\end{tabular}

\section{REFERENCES}

1. Amri, R., Marpaung, N. L. \& Ervianto, E., Nurhalim. (2017). Design of Firing Detector System by Peat Land with Woody Peat Types Using its Heat Characteristics. In IEEE $5^{\text {th }}$ International Conference on Instrumentation, Control, and Automation (ICA), Aug. 9-11, Yogyakarta, Indonesia (pp.130-134).

2. Atmel (2010). Atmega328 Datasheet, Atmel Corporation, 1-31. Available at: < <https:// www.alldatasheet.com/datasheet-pdf/ pdf/392243/ATMEL/ATMEGA328.html>, last accessed: April 16, 2019.

3. Barman, P., Raut, S., Sen, S. K., Shaikh, U., Bandyopadhyay, P. \& Mohapatra, P. K. D. (2017). Effect of a three-component bacterial consortium in white shrimp farming for growth, survival and water quality management, Acta Biologica Szegediensis, 61(1), 35-44.
The temperature and salinity monitoring implementations were practical because dissolved oxygen partially depends upon both parameters (Kayalvizhi et al., 2015). Nevertheless, the salinity, dissolved oxygen, and other parameters, such as viscosity, should be considered in future researches.

\section{Conclusion}

This research utilized a Zelio smart relay, as the main component for the water quality control of the miniature shrimp pond. Consequently, the control system needs an Arduino Uno microcontroller for the interfacing between the $\mathrm{pH}$ sensor and Zelio. It also used LabVIEW software for monitoring $\mathrm{pH}$ and temperature values in chart forms and saving data in Excel files.

The use of the aerator and water pump as the control system was proved to be an effective procedure for keeping the temperature at around $25.4^{\circ} \mathrm{C}$. This control system produced the new temperature condition, which was within the specified range of $25-32^{\circ} \mathrm{C}$. Also, the $\mathrm{pH}$ was effectively maintained at the required range of 7.0-8.0. In general, the system worked according to these parameters - the $\mathrm{pH}$ above 7.0 and the temperature maintained below $32^{\circ} \mathrm{C}$, which could represent the required conditions of the water from shrimp ponds.
4. Boyd, C. E. (2003). Bottom Soil and Water Quality Management in Shrimp Ponds, Journal of Applied Aquaculture, 13(1-2), 11-33.

5. Bui, T. D., Van, J. L. \& Austin, C. M. (2012). Impact of Shrimp Farm Effluent on Water Quality in Coastal Areas of the World Heritage-Listed Ha Long Bay, American Journal of Environmental Sciences, 8(2), 104-116.

6. Chandanapalli, S. B., Reddy, S. E. \& Lakshmi, R. D. (2014). Design and Deployment of Aqua Monitoring System Using Wireless Sensor Networks and IARKick, Journal of Aquaculture Research \& Development, 5(7), 1-10. 
7. Chaudhari, R. P. \& Chopade, M. K. (2016). Ethernet Based Field Control Module for Industrial Process Monitor and Control Using ATmega328. In International Conference on Communication and Signal Processing, Apr. 6-8, India (pp. 2098-2101).

8. Chuntapa, B., Powtongsook, S. \& Menasveta, P. (2003). Water quality control using Spirulina platensis in shrimp culture tanks, Aquaculture, 220(1-4), 355-366.

9. DFRobot (2008). PH meter (SKU: SEN0161), DFRobot, 1-20. Available at: $<$ https:// media.digikey.com/ pdf/ Data\%20 Sheets/ DFRobot\%20PDFs/SEN0161 SEN0169 Web.pdf>.

10. Diniş, C. M., Popa, G. N. \& Iagăr, A. (2017). Automation Heating and Pumping for Water Using Zelio PLC. In $10^{\text {th }}$ International Symposium on Advanced Topics in Electrical Engineering, March 23-25, Bucharest, Romania (pp. 903-908).

11. Diniş, C.M.\&Popa, G. N. (2018).Automation of a Pneumatic Cement Transport Installation Using PLC. In International Conference on Applied and Theoretical Electricity (ICATE), Craiova, Romania, 4-6 Oct.

12. Ferreira, N. C., Bonetti, C. \& Seiffert, W. Q. (2011). Hydrological and Water Quality Indices as management tools in marine shrimp culture, Aquaculture, 318(3-4), 425-433.

13. Habaki, H., Aoki, Y., Egashira, R., Sato, K. \& Eksangsric, T. (2016). Effects of Sterile Ulva sp. Growth Rate on Water Quality Control of Intensive Shrimp Culture Pond in Developing Countries, Chemical and Biochemical Engineering Quarterly, 30(3), 341-349.

14. Hakim, N. F. A., Najmurrokhman, A., Arifianto, M. S. \& Munir, A. (2018). SFCW Signal Generator Based on ATMega328 Microcontroller and R12R Ladder Networks. In Electrical Power, Electronics, Communications, Controls and Informatics Seminar (EECCIS), 9-11 Oct., Batu, East Java, Indonesia (pp.177-180).

15. Kayalvizhi, S., Reddy, K. G, Kumar, V. P \& Prasanth, V. N. (2015). Cyber Aqua Culture Monitoring System Using Arduino and Raspberry Pi, International Journal of Advanced Research in Electrical, Electronics and Instrumentation Engineering, 4(5), 4554-4558.
16. Kebairi, A., Becherif, M. \& Bagdouri, M. E. (2015). Modeling, simulation and identification of an engine air path electromechanical actuator, Control Engineering Practice, 34, 88-97.

17. Keller, J. P. (2006). Interactive control system design, Control Engineering Practice, 14, 177-184.

18. Kiruthika, S. U., Raja, S. K. S. \& Jaichandran, R. (2017). IOT based Automation of Fish Farming, Journal of Advanced Research in Dynamical and Control Systems, 9(1), 50-57.

19. Latina, Ann, M. E., Baking, Howard, D. L., Fernandez, Emery, J. S., Guevarra, Davey, A. R. \& Rastrullo, James, R. R. (2017). Development of device under test (DUT) board of LM741 op-amp IC for test development and measurement track of Mapua University. In 2017 IEEE $9^{\text {th }}$ International Conference on Humanoid, Nanotechnology, Information Technology, Communication and Control, Environment and Management (HNICEM), 1-3 Dec., Manila, Philippines (pp. 1-4).

20. Le, D., Pietrzak, B. W. \& Shaver, G.M. (2014). Dynamic surface control of a piezoelectric fuel injector during rate shaping, Control Engineering Practice, 30, 12-26.

21. Li, J., Albri, F., Maier, R. R. J., Shu, W., Sun, J., Hand, D. P. \& MacPherson, W. N. (2015). A Micro-Machined Optical Fiber Cantilever as a Miniaturized $\mathrm{pH}$ Sensor, IEEE Sensors Journal, 15(12), 7221-7227.

22. Liu, C., Ren, W., Zhang, B. \& Changyi, Lv. (2011). The application of soil temperature measurement by LM35 temperature sensors. In Proceedings of 2011 International Conference on Electronic \& Mechanical Engineering and Information Technology, 12-14 Aug., Harbin, China (pp.1825-1828).

23. Mahmud, K., Alam, Md. S. \& Ghosh, R. (2013). Design of digital thermometer based on PIC16F77A single chip microcontroller. In $3^{\text {rd }}$ International Conference on Consumer Electronics, Communications and Networks, 20-22 Nov., IEEE, Xianning, China (pp. 246-249).

24. Makmur, Suwoyo, H. S., Fahrur, M. \& Syah, R. (2018). The Influence of the Number of Pond Bottom Aeration Points on White Shrimp Farming, Litopenaeus vannamei, Jurnal Ilmu dan Teknologi Kelautan Tropis, 10(3), 727-738. 
25. Mangampa, M. (2015). Dynamics of Bacterial Populations in Water and Sediment of Ponds on Strengthening Extensive Plus Vaname Shrimp Cultivation Through Feed Rotation (in Indonesian), Berkala Perikanan Terubuk, 43(2), 25-35.

26. Milstein, A., Islam, M. S., Wahab, M. A., Kamal, A. H. M. \& Dewan, S. (2005). Characterization of water quality in shrimp ponds of different sizes and with different management regimes using multivariate statistical analysis, Aquaculture International, 13(6), 501-518.

27. National Instruments (2013). LabVIEW ${ }^{\mathrm{TM}}$, Getting Started with LabVIEW, National Instruments, Hardware: Acquiring Data and Communicating with Instruments (Windows), 4.1-12. Available at: <http://www.ni.com/pdf/ manuals $>$.

28. Pirzan, A. M. \& Utojo (2013). Variable Effect of Water Quality on Productivity of Vaname Shrimp (Litopenaeus vannamei) in Pertambakan Region Gresik Regency, East Java (in Indonesian), Biosfera, 30(3), 1-8.

29. Schneider Electric (2018). Smart relays Zelio Logic, Catalog September, 1-42. Available at: $<$ http://download.schneider-electric.com>.

30. Shaari, A. L., Surif, M., Latiff, F. A., Omar, W. M. W. \& Ahmad, M. N. (2011). Monitoring of Water Quality and Microalgae Species Composition of Penaeus monodon Ponds in Pulau Pinang, Malaysia, Tropical Life Sciences Research, 22(1), 51-69. Penerbit Universiti Sains Malaysia.

31. Swami, N. V. \& Jarali, V. M. (2017). Performance Measurement of Laser Communication Prototype in Free Space for Water Dam using ATmega328 and Comparison with ZigBee Technology. In
International Conference on Big Data, IoT and Data Science (BID), Vishwakarma Institute of Technology, Pune, Dec. 20-22 (pp.167-170).

32. Tahe, S. \& Nawang, A. (2012). Yuwana Shrimp Vaname Response (Litopenaeus vannamei) at Different Salinity Levels (in Indonesian). In Prosiding Indoaqua - Forum Inovasi Teknologi Akuakultur (pp.77-83).

33. Tahe, S. \& Suwoyo, H. S. (2011). Growth and Synthesis of Vaname Shrimp (Litopenaeus vannamei) with Different Feed Combinations in Controlled Containers (in Indonesian), Jurnal Riset Akuakultur, 6(1), 31-40.

34. Taryana, N., Waluyo \& Ismaya, A. (2017). Design of Shrimp Pond Water Quality Parameter Control System Model Using Zelio SR3B101BD and Arduino Uno (in Indonesian). In Prosiding Seminar Nasional Sains dan Teknologi Terapan IV (SNTE KPAN V), 2017, Surabaya, 19 Oct. (pp. B181-B188).

35. Texas Instruments (1999). LM79XX Series 3-Terminal Negative Regulators, Texas Instruments Incorporated, 1-9.

36. Texas Instruments (2003). $\mu \mathrm{A} 7800$ Series Positive-Voltage Regulators, SLVS056J, Texas Instruments Incorporated, 1-8. Revised: May, 2003.

37. Texas Instruments (2016). LM1117 800-mA Low-Dropout Linear Regulator, SNOS412N, Texas Instruments Incorporated, 1-22. Revised: January, 2016.

38. Yuan, H. B., Na, H. C. \& Kim, Y. B. (2018). Robust MPC-PIC force control for an electro-hydraulic servo system with pure compressive elastic load, Control Engineering Practice, 79, 170-184. 